\title{
Palaeoenvironmental significance of Toarcian black shales and event deposits from southern Beaujolais, France
}

\author{
GUILLAUME SUAN*†‡§, LOUIS RULLEAU $\uparrow$, EMANUELA MATTIOLI $\ddagger$, BAPTISTE \\ SUCHÉRAS-MARX\|, BRUNO ROUSSELLEף, BERNARD PITTET $\ddagger$, \\ PEGGY VINCENT\#, JEREMY E. MARTIN**, ALEX LÉNA \\ JORGE. E. SPANGENBERG $†$ KARL B. FÖLLMI \\ * Institute of Geosciences, Goethe University Frankfurt, Altenhöferallee 1, D-60438 Frankfurt am Main, Germany \\ $\dagger$ Institute of Earth Sciences, University of Lausanne, Géopolis, CH-1015 Lausanne, Switzerland \\ łUMR CNRS 5276 LGLTPE, Université Lyon 1, Campus de la Doua, Bâtiment Géode, \\ F-69622 Villeurbanne Cedex, France \\ ๆEspace Pierres Folles, 116 chemin du Pinay, F-69380, St Jean des Vignes, France \\ ॥Department of Earth Sciences, Palaeobiology Programme, Uppsala University, Villavägen 16, \\ Uppsala, SE-75 236, Sweden \\ \#Staatliches Museum für Naturkunde, Rosenstein 1, D-70191 Stuttgart, Germany \\ ** School of Earth Sciences, University of Bristol, BS8 1RJ, Bristol, United Kingdom
}

(Received 30 March 2012; accepted 1 November 2012; first published online 7 February 2013)

\begin{abstract}
New sedimentological, biostratigraphical and geochemical data recording the Toarcian Oceanic Anoxic Event (T-OAE) are reported from a marginal marine succession in southern Beaujolais, France. The serpentinum and bifrons ammonite zones record black shales with high (1-10 wt \%) total organic carbon contents (TOC) and dysoxia-tolerant benthic fauna typical of the 'Schistes Carton' facies well documented in contemporaneous nearby basins. The base of the serpentinum ammonite zone, however, differs from coeval strata of most adjacent basinal series in that it presents several massive storm beds particularly enriched in juvenile ammonites and the dysoxia-tolerant, miniaturized gastropod Coelodiscus. This storm-dominated interval records a marked negative $5 \%$ carbonate and organic carbon isotope excursion being time-equivalent with that recording storm- and mass flow-deposits in sections of the Lusitanian Basin, Portugal, pointing to the existence of a major tempestite/turbidite event over tropical areas during the T-OAE. Although several explanations remain possible at present, we favour climatically induced changes in platform morphology and storm activity as the main drivers of these sedimentological features. In addition, we show that recent weathering, most probably due to infiltration of $\mathrm{O}_{2}$-rich meteoric water, resulted in the preferential removal of ${ }^{12} \mathrm{C}$-enriched organic carbon, dramatic TOC loss and total destruction of the lamination of the black shale sequence over most of the studied exposure. These latter observations imply that extreme caution should be applied when interpreting the palaeoenvironmental significance of sediments lacking TOC enrichment and lamination from outcrops with limited surface exposures.
\end{abstract}

Keywords: Toarcian Oceanic Anoxic Event, Schistes Carton, oxygen-deficiency, organic-rich deposits, weathering, carbon isotope excursion, ammonites, event deposits.

\section{Introduction}

The Early Jurassic period was marked by a short $(<1 \mathrm{Ma})$ interval of extensive organic-rich deposition and extreme environmental changes termed the Toarcian Oceanic Anoxic Event (T-OAE; 183 Ma). In most documented marine successions of this age, the maximum of organic carbon enrichment, interpreted as the consequence of widespread marine oxygen deficiency, broadly coincides with marked negative and positive carbon isotope excursions, abrupt sedimentary changes, calcification crises and marine invertebrate extinctions (e.g. Jenkyns, 1988; Röhl et al. 2001; Cohen, Coe \& Kemp, 2007; Caswell, Coe \& Cohen, 2009; Mattioli et al. 2008, 2009; Suan et al. 2010, 2011). These perturbations are thought to reflect deep and global disturbance of both the carbon cycle and

§Author for correspondence: guillaume.suan@univ-lyon1.fr climate that have been commonly related (more or less directly) to the eruption of the Karoo-Ferrar large igneous province in southern Gondwana (e.g. Hesselbo et al. 2000; Pálfy \& Smith, 2000; Cohen, Coe \& Kemp, 2007; Svensen et al. 2007).

Although the sedimentary and geochemical record of the T-OAE has been intensively studied in basinal successions of northern Europe, data from shallower, marginal environments are scarce (Fig. 1), leading to large uncertainty concerning the geographical extent of environmental changes during the T-OAE. For instance, the lack of organic-carbon rich deposits in some marginal sections of northwestern Europe (e.g. southwest England, Spain) suggests that oxygendepletion only developed locally in European shelves (van de Schootbrugge et al. 2005; McArthur et al. 2008; Gómez, Goy \& Canales, 2008; Gómez \& Goy, 2011). In addition to this lack of organic carbon enrichment, the T-OAE interval in several sections of 


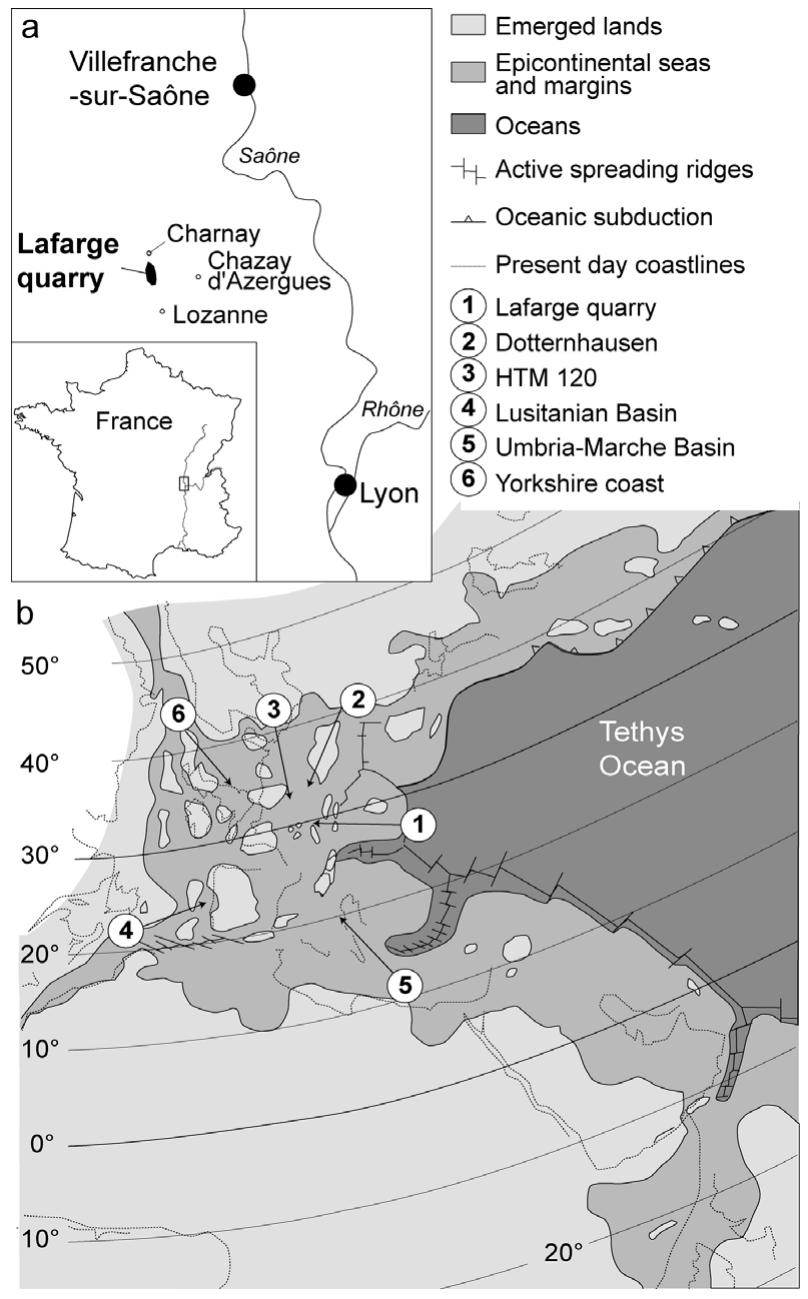

Figure 1. Location of the Lafarge cement quarry. (a) Modern location. (b) Location of the study site and that of contemporaneous sites discussed in the text with respect to Toarcian geography. Palaeogeographic map modified from Mattioli et al. (2008).

the Lusitanian Basin is dominated by gravity-flow and storm deposits (Duarte \& Soares, 1993; Hesselbo et al. 2007). These sedimentological features possibly reflect $\mathrm{CO}_{2}$-forced changes in hydrological cycling and storm intensity (Hesselbo et al. 2007), but the absence of such sedimentological features in other northwestern European sections may alternatively point to local, tectonically controlled changes in relative sea level (Duarte \& Soares, 1993; Kullberg et al. 2001; Suan et al. 2008b).

In this context, shallow-water deposits located between the northern and southern margin of the western Tethys might provide fundamental clues for constraining the possible links amongst changes in relative sea level, seawater oxygenation and regional oceanographic conditions across this key interval. The shallow-water fossiliferous succession exposed in the Beaujolais area (Rhône, southeastern France) preserves one of the most complete Toarcian sequences of northern Europe, extending from the lower Toarcian to the upper Aalenian. The middle Toarcian - lower Aalenian marls and limestones of this area have yielded rich ammonite assemblages that have been extensively studied and described, providing a valuable biostratigraphic framework for correlation between the northern and southern margins of the western Tethys (Elmi \& Rulleau, 1993; Rulleau, 2006). Interestingly, neither organic matter-rich sediments nor evidence for strong oxygen-deficiency have been reported in the lower Toarcian strata of the area, implying that bottom seawater might have remained well oxygenated throughout the early Toarcian period. However, the lower Toarcian succession of the Lafarge cement quarry has been comparatively less studied in terms of sedimentology and biostratigraphy, suggesting that these palaeoenvironmental conclusions might alternatively result from poor dating or incompleteness of the section.

In this paper we report new sedimentological, biostratigraphical and geochemical data from lowermiddle Toarcian sediments of the Lafarge cement quarry that offer insight into the expression of the TOAE in marginal area and provide new valuable bases for comparison with other contemporaneous localities. These results are then discussed within the context of the current debate about the nature and consequences of early Toarcian environmental changes.

\section{Geological setting and stratigraphy}

The Lower-Middle Jurassic strata of the southern Beaujolais area (Rhône Department, SE France; Fig. 1) were laid down in a series of relatively shallow extensional basins along the northeastern edge of the Central Massif (Elmi \& Rulleau, 1993). The area was subsequently severely faulted and uplifted during the Cenozoic Alpine orogeny, forming a horst-graben structure with a predominant SSW-NNE orientation (Elmi \& Rulleau, 1993). The Lafarge cement quarry near the villages of Belmont, Charnay, and SaintJean-des-Vignes (Fig. 1) exposes a very fossiliferous succession of mudstone, marlstone and limestone beds of Toarcian to Bajocian age that constitutes the best Jurassic exposure in the area ('Couches de Belmont'; Elmi \& Rulleau, 1991, 1993). The biostratigraphy of the exposures has been studied for more than 30 years, thereby constituting a reference section for regional correlations (Elmi \& Rulleau, 1991, 1993; Rulleau, 1997, 2006).

We recently carried out multidisciplinary fieldwork campaigns in the lowermost beds of the quarry to improve our understanding of the lower Toarcian interval, which was previously poorly exposed. A $\sim 2$ m-deep trench was excavated through the floor of the quarry to study the lowermost Toarcian succession. The stratigraphically lowermost part uncovered by the trench consists of a yellow-grey, massive dolomitic limestone bed that is particularly enriched in belemnite rostra in its topmost part ('lower belemnite bed'; Fig. 2). The base of the bed yielded ammonite specimens referable to Dactylioceras (Orthodactylites) crosbeyi, Dactylioceras (Orthodactylites) tenuicostatum and 


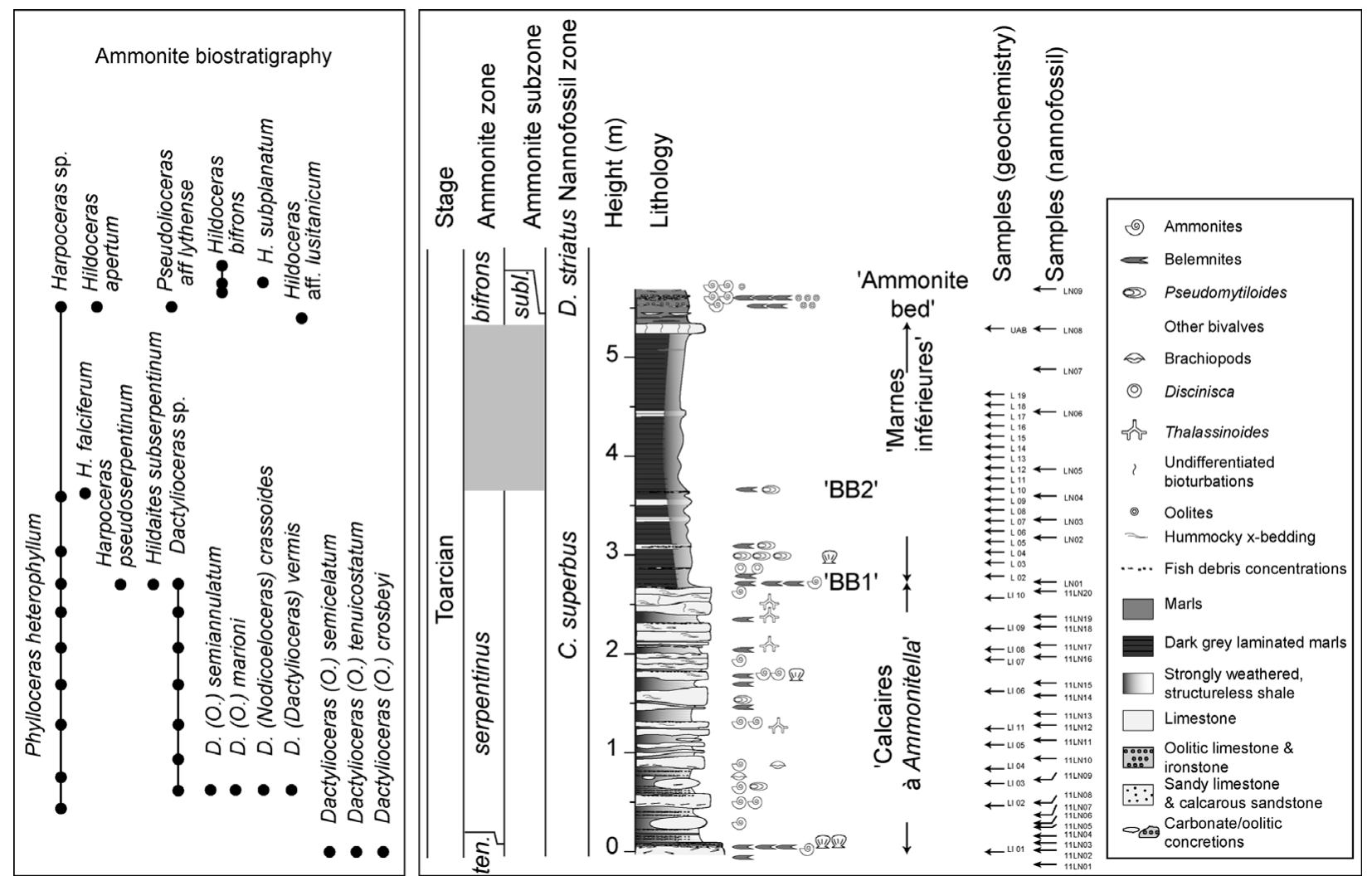

Figure 2. Lithological log of the studied section of the Lafarge cement quarry and occurrence of age diagnostic ammonites and nannofossil. Abbreviations: subl. - sublevisoni; ten. - tenuicostatum.

Dactylioceras (Orthodactylites) semicelatum, indicating that the lowermost part of the studied succession belongs to the tenuicostatum ammonite zone (Fig. 2). This bed is overlain by a $5 \mathrm{~cm}$-thick reddish bed enriched in oysters and bioclasts that likely corresponds to the reddish level mentioned by Rulleau (1997) at the transition of the tenuicostatum-serpentinum ammonite zones in another, disused part of the quarry. The overlying interval consists of a $2 \mathrm{~m}$ thick succession of decimetre-thick, partly dolomitized calcareous beds interbedded with severely weathered, yellowish plastic clays associated with ammonite-yielding concretions (Figs 2, 3b). The clay intervals commonly contain millimetre-thick laminae particularly enriched in fish debris, and preserve in some places less altered, blue-grey portions showing more distinct lamination. Most calcareous beds are sharp-based and laminated, and capped by thin horizons particularly enriched in disarticulated fish debris (bones and scales). The calcareous beds yielded relatively abundant belemnite rostra, juvenile and adult ammonites, bivalves (Pseudomytiloides dubius and other unidentified taxa) remains of marine reptiles and fishes and, at some levels, isolated brachiopod shells (Fig. 2). The ammonite fauna (H. serpentinum, strangewaysi and alternatum morphs, Harpoceras pseudoserpentinum) indicate that this calcareous interval belongs to the serpentinum zone and is therefore the lateral equivalent of the 'Calcaires Jaunes à Ammonitella' of Elmi \& Rulleau (1991, 1993; Fig. 2). The uppermost bed of the 'Calcaires Jaunes à Ammonitella' is a highly distinctive, irregular and massive limestone that forms the main basement of the southern part of the quarry.

The calcareous unit is capped by a $2.5 \mathrm{~m}$ thick marly interval (Fig. 2), equivalent to the 'Marnes inférieures' of Elmi \& Rulleau (1991), interbedded at its base with several fining upward, centimetre-thick pyritic horizons rich in fish debris and belemnite rostra ('bonebeds'; Figs 2, 3e). Non-weathered parts of the 'Marnes inférieures' consist of dark grey, finely laminated argillaceous marls containing isolated wood remains (some being preserved as 'jet'), sporadic bivalves (isolated and clustered specimens of Pseudomytiloides dubius, isolated specimens of Bositra and Plagiostoma) and thin-shelled inarticulate brachiopods (Discinacea papyracea). The middle part of this interval yielded two fragmentary specimens of Harpoceras falciferum, a species generally used as a marker of the uppermost part of the serpentinum zone (falciferum subzone; Howarth, 1992a, b; Gómez, Goy \& Canales, 2008). Nevertheless, this species ranges into the basal part of the bifrons zone in several German, English, Italian and Spanish sections (e.g. Riegraf, Werner \& Lörcher, 1984; Jenkyns et al. 1985; Howarth, 1992a, b; Gómez, Goy \& Canales, 2008), so that this interval may possibly belong to the basalmost bifrons zone (Fig. 2). Observations made on successive field campaigns revealed that the dark grey laminated argillaceous marls weathered rapidly into highly distinctive 'paper shales' that gave their name to the 'Schistes Carton' of the Paris Basin. Deeply weathered portions of the 'Marnes inférieures' are yellow, plastic and almost structureless (Fig. 3c) 

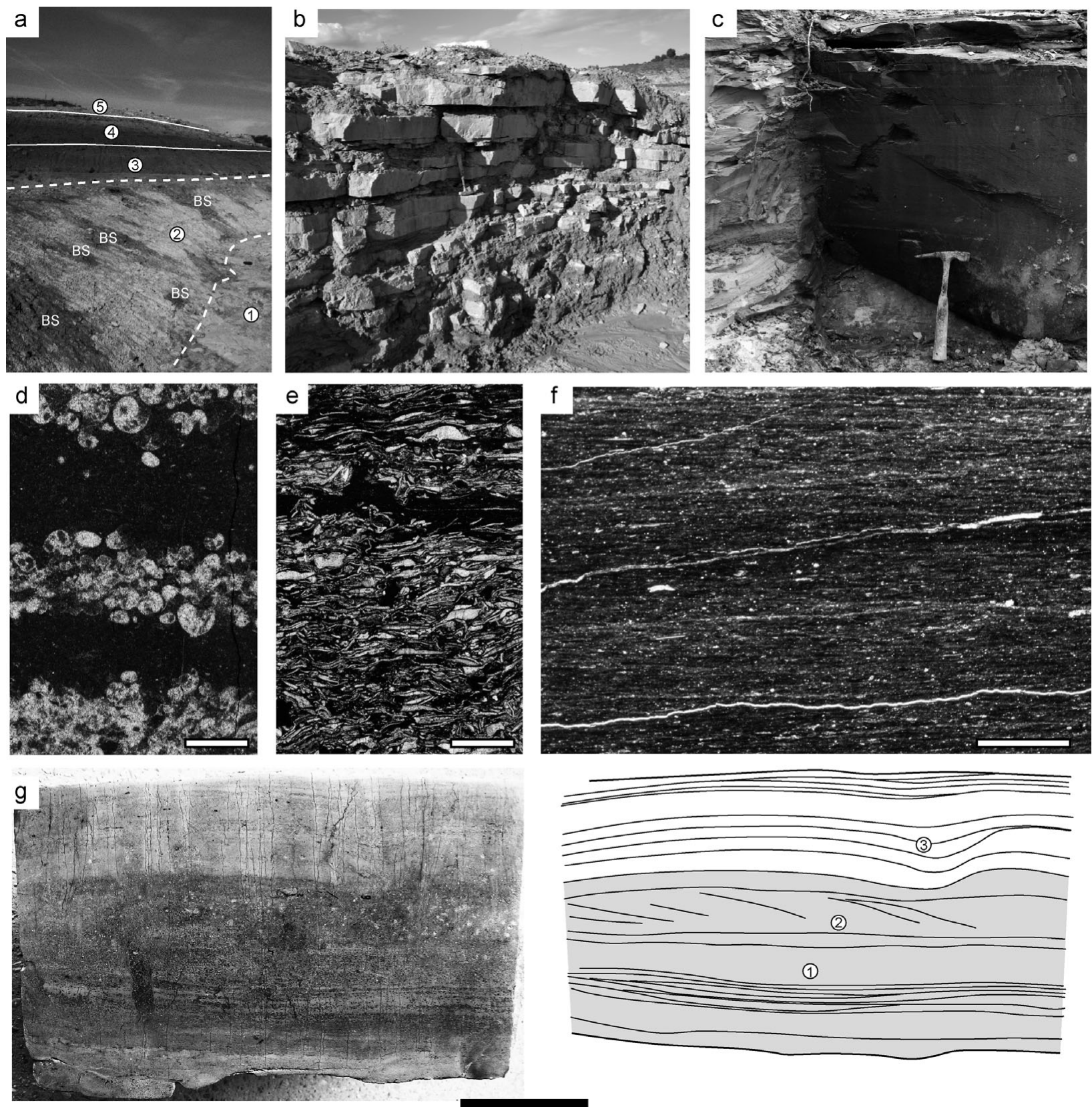

(1)

Figure 3. Field photographs of the basal Toarcian succession at the Lafarge quarry site and microphotographs of slabbed and thin sections of some representative samples. (a) Overview of the section showing the top of the uppermost massive limestone bed of the 'Calcaires Jaunes à Ammonitella' (1), black shales (BS) of the 'Marnes inférieures' and their extremely weathered, light coloured clay equivalent (2), the middle Toarcian marls (3), the upper Toarcian oolitic limestone bearing marls (4) and the lower Aalenian sandy limestone beds (5). (b) Detail of the exposure of the 'Calcaires Jaunes à Ammonitella' between 0 and $2.3 \mathrm{~m}$. (c) Close-up view of the black shales of the lower part of the 'Marne inférieures' between 2.4 and $3.5 \mathrm{~m}$, showing the strong weathering aspect on the left side. (d) Photomicrograph of the top bed of the 'Calcaires Jaunes à Ammonitella', showing the normally graded Coelodiscus shells concentrated into distinct lenses (scale bar $=1 \mathrm{~mm}$ ). (e) Photomicrograph of a thin pyritic bed of the base of the 'Marnes Inférieures' (bed 'BB1' in Fig. 2) showing high concentrations of phosphatic fish debris and thin shelled bivalves (scale bar $=1 \mathrm{~mm}$ ). (f) Photomicrograph of a black shale sample from the lower part of the 'Marnes Inférieures', illustrating the strong sub-horizontal lamination of the organic-rich deposits (scale bar $=1 \mathrm{~mm}$ ). (g) Photograph (left panel) and interpretative drawing (right panel) of a vertical section across the topmost bed of the 'Calcaires Jaunes à Ammonitella', showing a coarser, bioturbated basal sequence consisting of Coelodiscus-yielding lamina (1), a middle sequence with cross lamination (2) and an upper, fine-grained laminated sequence with probable escape structures (3) (scale bar $=5 \mathrm{~cm})$.

and appear identical in all respects to the plastic yellow clays of the underlying unit. The non-weathered parts of the 'Marnes inférieures' are preserved as small, fracture-bounded and discontinuous patches that, compared to the weathered part, crop out on a very limited surface of the studied exposure (Figs 2, 3a, c; see also Fig. S1 in the online Supplementary Material available at http://journals.cambridge.org/geo). The upper part of the 'Marnes inférieures' displays a gradual change in colour from dark grey to purple grey when non-weathered and from yellow to bright purple-red when weathered. The argillaceous marls of 


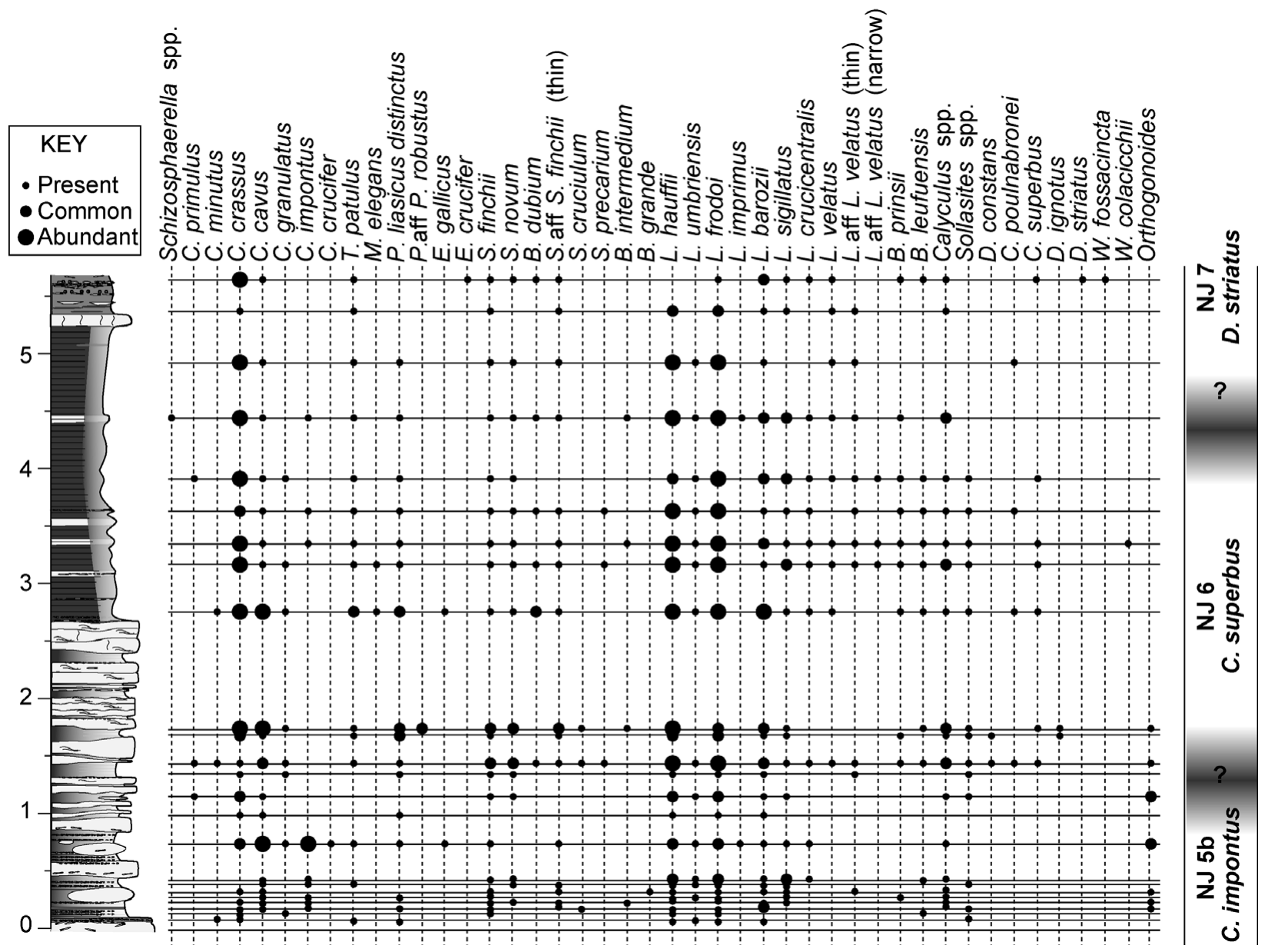

Figure 4. Calcareous nannofossil range chart for the Toarcian succession from the Lafarge quarry site.

the 'Marnes inférieures' are capped by a bioturbated and micritic light grey argillaceous limestone bed. The surface of the bed yielded Hildoceras aff. lusitanicum and therefore belongs to the bifrons zone (sublevisoni subzone). Overlying purplish grey shales (reddish to pinkish when weathered) are strongly bioturbated (Chondrites) and contain disseminated phosphatized and ferruginous ooliths as well as numerous phosphatized ammonites and small belemnites ('ammonite bed'; Fig. 2). The ammonite assemblage (Harpoceras subplanatum, Hildoceras apertum, H. bifrons, Pseudolioceras aff. lythense) is characteristic of the bifrons zone (bifrons subzone; Fig. 2). Equivalent levels from another part of the quarry yielded a large, subcomplete ichthyosaur specimen in the early 1980s (Elmi \& Rulleau, 1991; Martin et al. 2012). The top of this fossil-rich interval contains isolated bone elements of marine reptiles and large, saucershaped argillaceous limestone concretions encrusted by serpulids and bivalves.

\section{Material and methods}

Hand-samples of non-weathered bulk rock were collected throughout the measured succession for sedimentological, micropalaeontological and geochemical analyses. Unfortunately, it was impossible to collect non-weathered samples from the argillaceous interbeds of the lower part $(<2.3 \mathrm{~m})$ and geochemical data from this part were obtained using solely carbonate rich samples, leading to coarser sample spacing in this part of the studied section (Fig. 2). Non-weathered and strongly weathered samples were collected along two different horizons of the 'Marnes inférieures' to investigate the effect of weathering on the organic carbon isotope compositions and the proportions of carbonate and organic carbon. Slabbed and thin sections of the limestone and thin pyritic beds were prepared to characterize their macro- and microstructural aspects and micropalaeontological content.

Microscope slides for nannofossil identification were prepared by powdering small amounts of bulk rock and diluting with water before spreading onto a cover slide (Bown \& Young, 1998). Nannofossil identifications and semiquantitative analyses were performed in 25 samples under a light polarizing Zeiss microscope at a $1000 \times$ magnification. The studied samples are closely spaced in the basal part of the section, whilst sampling was at a lower resolution in the upper part of the studied interval (Fig. 4).

Bulk rock powdered samples for stable isotope analyses were obtained by crushing $3 \mathrm{~g}$ of clean bulk sediment without fractures, calcite veins and macrofossils. Carbon isotope compositions of bulk 
carbonate $\left(\delta^{13} \mathrm{C}_{\text {carb }}\right)$ were measured using a Thermo Fisher GasBench II preparation device connected to a Delta Plus XL isotope ratio mass spectrometer (IRMS) at the University of Lausanne. The $\mathrm{CO}_{2}$ was extracted from an aliquot of 300-600 $\mu \mathrm{g}$ of powdered rock by anhydrous phosphoric acid at $70^{\circ} \mathrm{C}$. Stable isotope compositions of oxygen and carbon are expressed as per mil deviation relative to VPDB standard. Analytical precision, monitored by analyses of the laboratory standard Carrara marble was better than $\pm 0.05 \%$ o for carbon and $\pm 0.1 \%$ for oxygen. Carbonate contents $\left(\mathrm{CaCO}_{3}\right.$, in wt \%) were determined using the total peak areas of the calcite standard and samples. The resulting carbonate contents were very similar to that obtained by weighing the amount of the dry decarbonated residue following overnight acidification of about $2 \mathrm{~g}$ of dry bulk powdered sediment with $1 \mathrm{M} \mathrm{HCl}$. Only this latter method was used to estimate the amount of calcium carbonate in the samples chosen for testing the effect of weathering.

Stable isotope compositions of bulk organic carbon $\left(\delta^{13} \mathrm{C}_{\text {org }}\right)$ were determined by analyzing 0.3 to $12 \mathrm{mg}$ of decarbonated sample with a Thermo Fisher Flash Elemental Analyzer 1112 connected to the continuous flow inlet system of a MAT 253 isotope ratio mass spectrometer (EA-IRMS) at the Institute of Geosciences in the Goethe University Frankfurt. Prior to analysis, samples were decarbonated using excess $1 \mathrm{M} \mathrm{HCl}$ for $48 \mathrm{~h}$ in a sand bath at $50^{\circ} \mathrm{C}$, rinsed with deionised water and centrifuged until neutrality was reached. Analytical precision and accuracy were monitored by replicate analyses of USGS 24 graphite standard and unknown samples. The reproducibility was better than $0.1 \%$ o $(1 \sigma)$. Total organic carbon (TOC, in wt \%) contents were determined using the EA peak areas.

\section{Results}

\section{4.a. Sedimentology}

The calcareous beds of the 'Calcaires Jaunes à Ammonitella' unit are erosive-based, distinctly laminated and normally graded (Fig. 3b, g). These beds frequently show low angle cross bedding (Fig. 3g) that may be associated with abundant juvenile ammonites and Thalassinoides burrows at their base. All these features indicate that the deposition of these beds took place under storm-induced oscillatory currents (distal tempestites sensu Aigner, 1985). The calcareous beds and concretions contain tremendous amounts of small calcareous shells commonly replaced by sparitic cements that form laterally discontinous laminae (Fig. 3d). Elmi \& Rulleau (1991) initially interpreted these tiny shells as the remains of juvenile ammonites ('Ammonitella'). Although the beds studied here do indisputably preserve large amounts of juvenile ammonites in their basal part (not shown), the new observations reveal that chambers are clearly absent in both small and large specimens (Fig. 3d). Accordingly, the small shells most probably belong to the minute gastropod genus Coelodiscus, which occurs very commonly in time equivalent strata of Germany, England and southern France (e.g. Riegraf, Werner \& Lörcher, 1984; Harries \& Little, 1999) and can be confused with juvenile ammonites (Etches, Clarke \& Callomon, 2009). It is noteworthy, however, that the abundance of Coelodiscus specimens in the lower Toarcian strata of the Lafarge quarry appears far higher than that reported in coeval successions (see Section 5.b). Therefore, the lowermost $\sim 2.5 \mathrm{~m}$ thick calcareous unit of the lower Toarcian sequence in the Lafarge quarry should more appropriately be referred to as 'Calcaires Jaunes à Coelodiscus', but since it also contains abundant juvenile ammonites it appears preferable to keep the former lithostratigraphic name for the sake of nomenclatural stability.

The thin sections of the basal pyritic beds of the 'Marne inférieures' ('bonebeds') show that they are particle-supported and mainly cemented by pyrite (Fig. 3e). The particles mainly consist of disarticulated angular fish debris, with subordinate amounts of thin and commonly pyritized bivalve shells, as well as scarce benthic foraminifera (not shown). The particles are well-sorted and poorly graded (Fig. 3e), while the belemnites concentrated in these beds do not show preferential orientation, as has been also documented in comparable beds of the falciferum-bifrons transition in the Posidonia Shale in southwestern Germany (Röhl \& Schmid-Röhl, 2005). These features indicate that the deposition of these distinctive beds likely resulted from repeated, non-directional oscillatory currents (winnowing).

\section{4.b. Geochemistry}

The geochemical data are reported in the online Supplementary Material at http://journals.cambridge.org/geo and in Figure 5. The samples of the calcareous unit show elevated $\mathrm{CaCO}_{3}$ concentrations between 80 and $93 \mathrm{wt} \%$, while those of the 'Marnes inférieures' show values between 26 and $43 \mathrm{wt} \%$ (Fig. 5). The nonweathered samples collected from $3.65 \mathrm{~m}$ (sample $\mathrm{BB} 2-\mathrm{NW}$ ) and $5.25 \mathrm{~m}$ (sample UAB-NW), have $\mathrm{CaCO}_{3}$ contents of 31 and $22 \mathrm{wt} \%$, respectively, and the strongly weathered samples collected in the same two horizons have $\mathrm{CaCO}_{3}$ contents of 28 (sample BB2$\mathrm{W})$ and $22 \mathrm{wt} \%$ (Fig. 5).

Total organic carbon contents are low in the calcareous beds of the basal part of the section (between 0.14 and $1 \mathrm{wt} \%$ ) and high in the non-weathered marly unit (between 2.4 and $9.6 \mathrm{wt} \%$ ). The non-weathered samples collected at $3.65 \mathrm{~m}$ (sample BB2-NW) and $5.25 \mathrm{~m}$ (sample UAB-NW), have TOC contents of 6.7 and $5 \mathrm{wt} \%$, respectively, and the strongly weathered samples collected in the same two horizons have TOC contents of 0.1 (sample BB2-W) and $0.2 \mathrm{wt} \%$ (Fig. 5).

The $\delta^{13} \mathrm{C}_{\text {org }}$ and $\delta^{13} \mathrm{C}_{\text {carb }}$ profiles record comparable changes through the lower part of the succession. Both records reveal high values in the massive limestone bed of the lowermost part of the measured section 


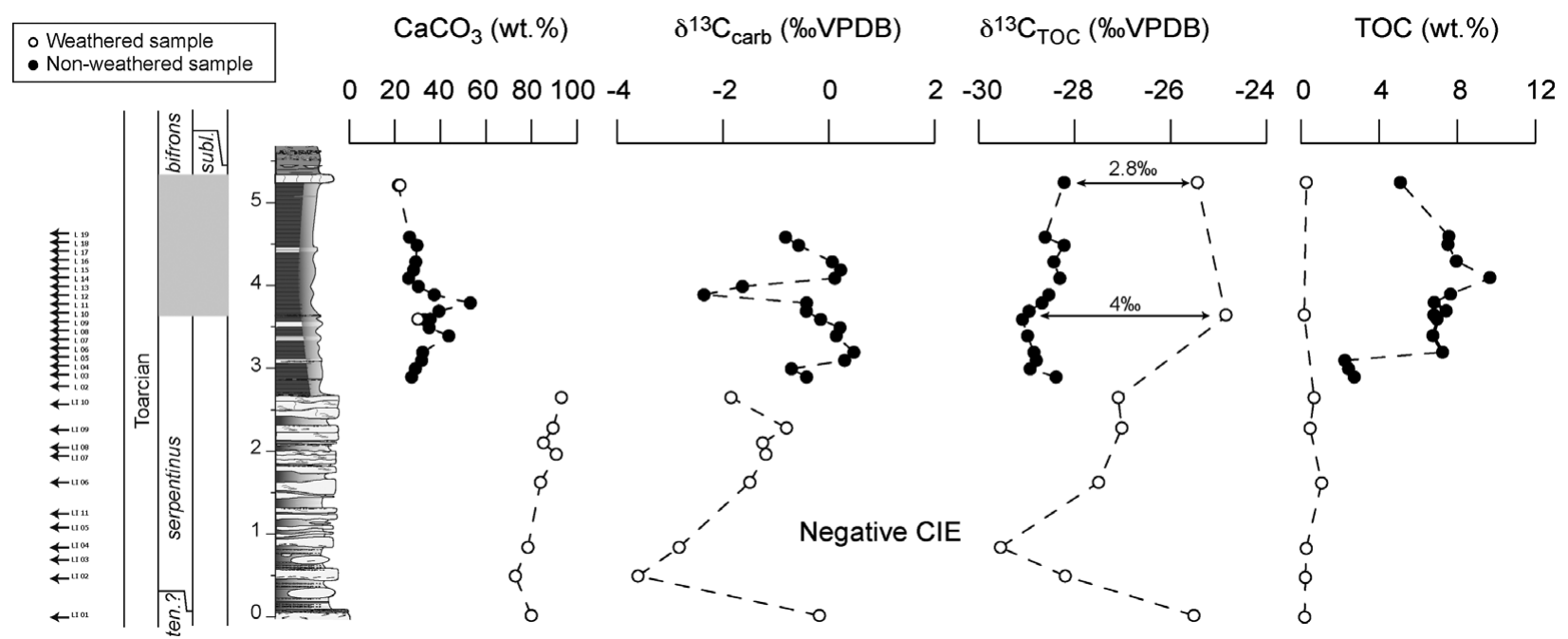

Figure 5. Geochemical data for the Toarcian succession from the Lafarge quarry site. Abbreviations: CIE - carbon isotope excursion; subl. - sublevisoni; ten. - tenuicostatum; TOC - total organic carbon.

('lower belemnite bed') and lowest values at the base of the 'Calcaires Jaunes à Ammonitella'. Carbon isotope values then increase at the top of the 'Calcaires Jaunes à Ammonitella', forming a distinct negative carbon isotope excursion (CIE) (Fig. 5). The $\delta^{13} \mathrm{C}_{\text {carb }}$ values increase towards the top of the 'Calcaires Jaune à Ammonitella' and decline slightly in the upper part of the 'Marnes inférieures', forming an approximately $1 \%$ positive excursion. The $\delta^{13} \mathrm{C}_{\mathrm{org}}$ record a similar shift, but return to more negative values $(\sim-28 \%)$ in the non-weathered portion of the 'Marnes inférieures' (Fig. 5).

\section{4.c. Calcareous nannofossils}

Nannofossil abundance is scarce at the base of the section until $0.37 \mathrm{~m}$, and slightly increases upsection (Fig. 4). Preservation varies from moderate to good. The studied section displays a nannofossil assemblage typical of the NW Europe domain (Bown, 1987; Bucefalo Palliani, Mattioli \& Riding, 2002; Mattioli et al. 2009). In detail, some Tethyan taxa, such as Schizosphaerella spp. or Mitrolithus jansae are missing, whilst high abundances of typical NW European taxa, such as Crepidolithus crassus and $C$. cavus (e.g. Mattioli et al. 2008) are recorded. This NW European affinity also influences biostratigraphy, as the first occurrence of Carinolithus superbus, marker for the NJ 6 Zone, is recorded at $1.39 \mathrm{~m}$ in the serpentinus ammonite Zone in an interval corresponding to the upper part of the negative CIE. This record is consistent with the observations of Bucefalo Palliani, Mattioli \& Riding (2002) for the Brown Moor BGS Borehole (England). Conversely, the first occurrence of $C$. superbus is recorded in various regions in the polymorphum/tenuicostatum ammonite Zone, in the interval prior to the negative CIE (Bucefalo Palliani \& Mattioli, 1998; Mattioli \& Erba, 1999; Bodin et al. 2010). The incertae sedis Orthogonoides is recorded in the interval corresponding to the negative
CIE (Fig. 4), a feature also seen in other records of the T-OAE (Hermoso et al. 2009; Mailliot et al. 2009).

\section{Discussion}

\section{5.a. Evidence for oxygen depletion in the Beaujolais area during the T-OAE}

The age of the Lafarge quarry succession can be confidently constrained using the ammonite and calcareous nannofossil assemblages. Although some portions of the organic carbon isotope profiles might reflect differential preservation (see Section 5.d), the distinct CIE occurring at the base of the serpentinum ammonite zone is comparable in shape and absolute values to that recorded in most contemporaneous successions (Fig. 6). We thus attribute the negative anomaly to the well-documented CIE characterizing the onset of the T-OAE in most known localities (Hesselbo et al. 2000, 2007; Röhl et al. 2001; Suan et al. 2011).

The lower Toarcian succession from the Beaujolais area shows some remarkable similarities with coeval deposits of nearby areas of the Quercy, Causses, Jura and Paris basins ('Schistes Carton'; Broquet, 1980; Baudin, Herbin \& Vandenbroucke, 1990; Guex et al. 2001; Emmanuel et al. 2006) but also from most sites of northwestern Europe (Posidonia Shales of southwestern and northwestern Germany, Jet Rock of the Yorkshire coast; Weitschat, 1973; Hallam, 1967; Röhl et al. 2001; Howarth, 1992a, b). The thin lamination and lack of bioturbation observed in black shales of the serpentinum-bifrons ammonite zones indicate that their deposition occurred under oxygen-depleted, presumably anoxic conditions. The presence of thin-shelled bivalves and brachiopods at several stratigraphically restricted horizons show that these conditions were temporally interrupted by less severe phases of deoxygenation, as suggested for contemporaneous deposits of southwestern Germany 


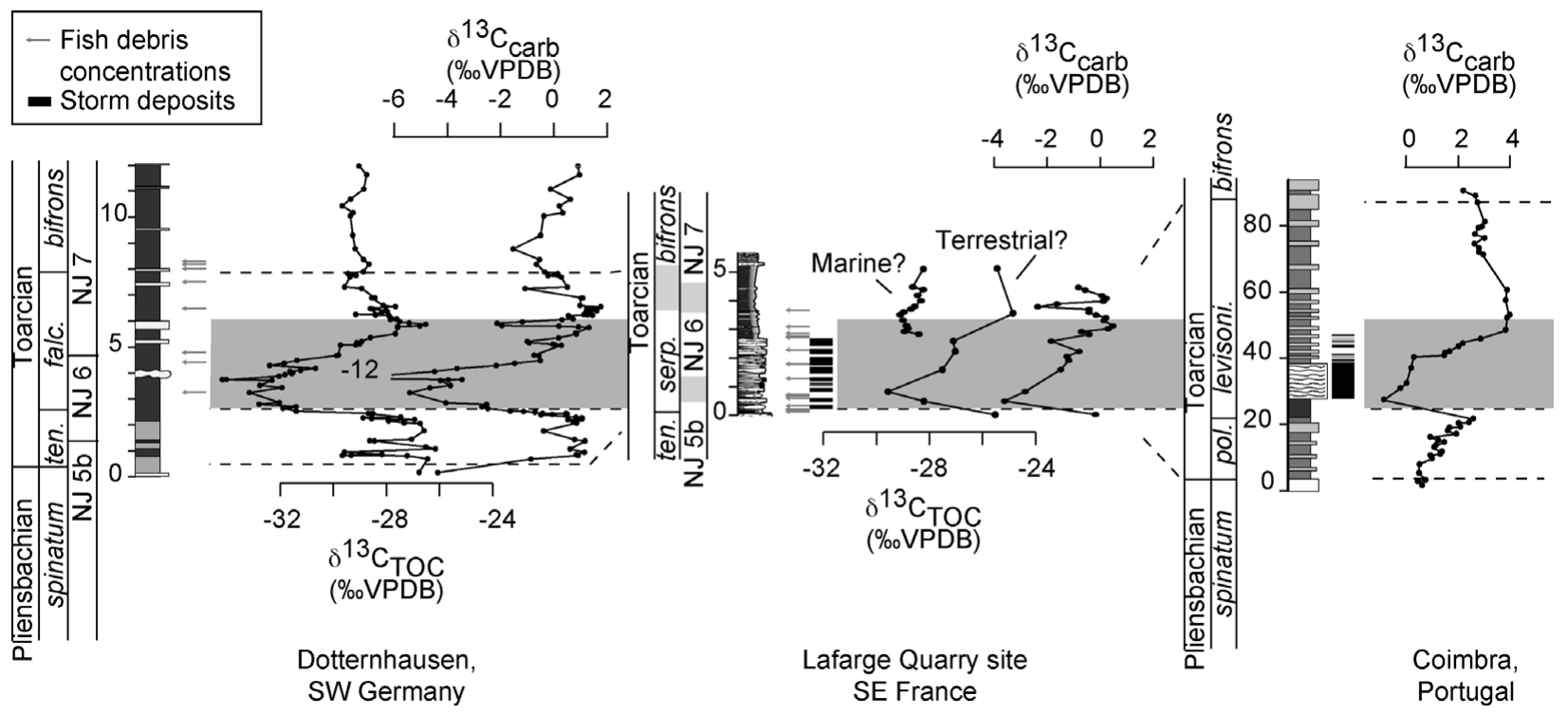

Figure 6. Comparisons of carbon-isotope and sedimentological data between the Lafarge Quarry site and contemporaneous successions of Dotternhausen (southwestern Germany) and Coimbra (Portugal). The organic carbon isotope profile on the left side at Lafarge Quarry originates from pristine black shales that are likely composed mainly of marine organic carbon, while the right profile originates from weathered samples that likely preserve alteration-resistant terrestrial particles (see text for details). Geochemical and lithological data for Dotternhausen from A. Schmid-Röhl (unpub. Ph.D. thesis, Univ. Tübingen, 1999), Röhl et al. (2001), and A. Frimmel (unpub. Ph.D. thesis, Univ. Tübingen, 2003); data from Coimbra are from Duarte, Oliveira \& Rodrigues, (2007). Abbreviations: falc. = falciferum; pol. $=$ polymorphum $;$ serp.$=$ serpentinum $;$ ten.$=$ tenuicostatum.

and England (Röhl et al. 2001; Caswell, Coe \& Cohen, 2009). The yellow clays of the 'Calcaires Jaunes à Ammonitella' (serpentinum ammonite zone) are structurally and faunistically almost identical to that of the upper part (Fig. 3a, b). Our results indeed indicate that weathered and non-weathered shales from the same horizons possess similar $\mathrm{CaCO}_{3}$ contents, but mainly differ in terms of their TOC contents (Fig. 5). It thus appears very likely that the yellow clays of the 'Calcaires Jaunes à Ammonitella' represent secondary by-products of originally organicrich, laminated shales. An additional, notable similarity between the Lafarge quarry site and other nearby records is the relatively elevated abundance of the incertae sedis Orthogonoides in the interval recording the CIE (Fig. 4), a feature also seen in the southern Paris Basin and the Causses area (Hermoso et al. 2009; Mailliot et al. 2009). Although the biological affinity of this taxon is enigmatic, previous authors noted that Orthogonoides is commonly associated with the nannofossil Calyculus, which might have been adapted to low-nitrate, stratified water bodies (Mattioli et al. 2008; Mailliot et al. 2009). Interestingly, this association is also evident at the base of the serpentinum zone in the Lafarge Quarry site (Fig. 4) and points to stressed calcareous nannofossil communities in the study site during the T-OAE.

Altogether, the new data from southern Beaujolais suggest that strong oxygen deficiency during the $\mathrm{T}$ OAE was not restricted to deep basinal areas of the European epicontinental seaway but extended towards the marginal marine areas located very close to the structural high of the Central Massif. Importantly, the successions of Beaujolais, England, Germany and
Luxembourg contrast markedly with those of several lower latitude sites in Portugal and Spain, where the levels equivalent to the serpentinum zone are almost devoid of evidence for strong oxygen depletion and 'black shales' are generally restricted to centimetre to decimetre-thick horizons at variable position within the CIE (Hesselbo et al. 2007; Gómez \& Goy, 2011). The more 'open-ocean' sections from central and northern Italy and those from Greece show an intermediate situation, with the 'black shales' sometime exceeding a few metres in thickness but being generally restricted to the negative CIE (e.g. Jenkyns, Grocke \& Hesselbo, 2001; Sabatino et al. 2009; Kafousia et al. 2011). These different lithological expressions of the T-OAE over a relatively confined palaeogeographical area confirm that, as has been suggested for other OAEs (e.g. Jenkyns, 2010; Trabucho Alexandre et al. 2010), oxygen depletion during the Toarcian period might have been strongly modulated by regional environmental conditions. In this regard, it is noteworthy that almost all sections where intense and protracted oxygen depletion has hitherto been reported (i.e. England, Germany, Luxembourg, France) are located within epicontinental basins bordered by extremely large landmasses (Fig. 1). Because the T-OAE occurred during an interval of extreme warming and possibly accelerated hydrological cycle (e.g. Bailey et al. 2003; Suan et al. 2010; Gómez \& Goy, 2011; Dera et al. 2011), widespread oxygen depletion during the T-OAE was possibly caused by enhanced primary productivity and density stratification that would have resulted from increased nutrient and freshwater input (Jenkyns, 1988; Baudin, Herbin \& Vandenbroucke, 1990; Cohen, Coe \& Kemp, 2007). In this context, the proximity of large landmasses, 
combined with a position within a humid climatic belt (Dera et al. 2009), may have strongly exacerbated oxygen deficiency in the northernmost areas of the European epicontinental seaway (e.g. Jenkyns, 1988; Baudin, Herbin \& Vandenbroucke, 1990; Bailey et al. 2003) and could hence explain the occurrence of strong oxygen depletion in marginal marine settings such as that recorded in southern Beaujolais. Other factors that might have led to these marked regional contrasts include current-induced nutrient 'trapping' (e.g. Meyer \& Kump, 2008; Trabucho Alexandre et al. 2010), irregular bottom topographies (Hallam \& Bradshaw, 1979; McArthur et al. 2008) and climatically controlled amplification of carbon sequestration by clay mineral assemblages (Kennedy \& Wagner, 2011). Further geochemical, mineralogical and modelling efforts are thus needed to constrain the most probable cause(s) of the strong vertical and horizontal redox gradients that developed over European shelves during the T-OAE.

\section{5.b. A tempestitic/turbiditic event of supra regional magnitude during the T-OAE}

The lower Toarcian strata from the Beaujolais area also reveal some remarkable lithological differences with most coeval nearby sites of northwestern Europe. Our observations indeed show that storm-related deposition of carbonate was volumetrically important in the serpentinum Zone at the studied site, while carbonate deposition reached a minimum in coeval basins of England, Germany and France (Röhl et al. 2001; Mattioli et al. 2009). The thin sections from the 'Calcaires Jaunes à Ammonitella' in southern Beaujolais reveal that the millimetre-sized shells of the gastropod Coelodiscus (see Section 4.a) are a major carbonate component of the calcareous beds (Fig. 3). Beds and concretions with abundant Coelodiscus have been also reported in coeval levels of southwestern Germany, southern France (Causses) and England (Riegraf, Werner \& Lörcher, 1984; Harries \& Little, 1999). However, the Coelodiscus beds in those localities are generally restricted to few concretionary horizons and, to our knowledge, have never been reported to form successions of several beds with such elevated abundances. Coelodiscus is commonly associated with organic-rich shales and it is therefore generally acknowledged that the genus thrived under low-oxygen levels (e.g. Etter, 1996). Nevertheless, the ecology of this genus is controversial, with some authors describing Coelodiscus as planktonic carnivore (Bandel \& Hemleben, 1987) and others regarding it as a truly epibenthic form (Einsele \& Mosebach, 1955; Fischer, 1961; Etter, 1996). Regardless, their tremendous abundance and extremely small size in the study site suggest that they may have developed and suffered mass-mortality during short-term (bloomlike) events; their preservation as normally graded laminae (Fig. 3d) additionally suggests that their shells were subsequently reworked and transported by storm-induced currents, eventually forming thick
Coelodiscus-beds interbedded with finer grained siliciclastic material.

The black shale sequence is also notable for the occurrence of several thin pyritic horizons enriched in belemnites and disarticulated fish debris (Fig. 3e). Very similar levels have also been documented in the black shale sequences of the falciferum-bifrons ammonite zones in northwestern Germany (Schmid-Röhl, unpub. Ph.D. thesis, Univ. Tübingen, 1999; Röhl et al. 2001; Röhl \& Schmid-Röhl, 2005) and Italy (Jenkyns, 1988). The genesis of these levels was previously attributed to sediment-starvation or winnowing and interpreted as indicative of a maximum flooding (Schmid-Röhl, unpub. Ph.D. thesis, Univ. Tübingen, 1999; Röhl et al. 2001; Röhl \& Schmid-Röhl, 2005). In southern Beaujolais and southwestern Germany, however, there are more than five levels dispersed throughout the succession (Fig. 6), making the maximum flooding interpretation rather unlikely. In this regard, it is noteworthy that the particles of the 'bonebeds' in the study site are well sorted, while many of these levels occur at the top of thick storm beds (Figs. 2, 3e and 6). These characteristics suggest that their genesis more probably resulted from repeated storm-induced cycles of winnowing and redeposition. This interpretation is in line with the storm origin proposed for coeval HCSbearing beds enriched in fish remains of the basal serpentinum Zone in the nearby Causses Basin (Leptolepis bed; Mailliot et al. 2009 and references therein).

Importantly, storm-related carbonate deposition has also been reported from contemporaneous sections located at lower palaeolatitudes, for instance in most known lower Toarcian sections of the Lusitanian Basin in Portugal (Duarte \& Soares, 1993) and, to a lesser extent, in some localities of the Umbria-Marche Basin in Italy (Monaco, 1994). In the deeper areas of these basins, this interval records abundant gravityflow deposits (Monaco, 1994; Hesselbo et al. 2007) which might be genetically linked, through massive sediment destabilization, to storm activity (Monaco, 1994; Myrow \& Southard, 1996). In Portugal, gravityflow and storm deposits make their appearance at the base of the CIE and disappear towards its top, consistent with a link with this severe carbon cycle perturbation (Hesselbo et al. 2007; Duarte, Oliveira \& Rodrigues, 2007). Nevertheless, it has been also suggested that these sedimentological features might reflect local tectonic uplift restricted to the Lusitanian Basin (Duarte \& Soares, 1993; Suan et al. 2008b). In this context, our new record is significant in showing that distal storm deposits are also recorded during the negative CIE in a marginal marine succession of southeastern France. In addition, Röhl et al. (2001) noted that at Dotternhausen, 'rare and thin silty layers $(<1 \mathrm{~mm})$, characterized by a sharp base, are only found within sediments of the elegantulum- and exaratum-subzones' and interpreted these layers as distal tempestites or turbidites. Remarkably, these two subzones also precisely correspond to the interval recording the negative CIE in this section. Finally, sharp-based, 
graded 'event' beds, also likely formed by stormdriven currents, were recently identified in coeval mudstones of the basal exaratum subzone of Yorkshire (Ghadeer \& Macquaker, 2012). These observations therefore imply that these sedimentological features are most likely not localized phenomena and point to the existence of a tempestitic/turbiditic event of supra-regional magnitude across tropical shelves of the western Tethys during the T-OAE.

\section{5.c. Transient shallowing, increase of storm activity or changes in platform morphology?}

The occurrence of storm and gravity deposits within the stratigraphically limited interval recording the Toarcian CIE in several contemporaneous, fine-grained successions at tropical latitudes can be attributed to three main mechanisms, namely transient shallowing event(s), changes in storm activity or shifts in sediment redistribution linked to changes in platform morphology. A classical sequence stratigraphic approach would tend to favour the former explanation, because storm deposits formed above the storm wave base are taken to reflect deposition at relatively shallow depth in most sequence stratigraphic models (e.g. Posamentier, Jervey \& Vail, 1988; Walker \& Plint, 1992). Nevertheless, a sea-level fall of significant magnitude during the CIE would have led to substantial changes in base level in nearby emerged areas of the study site (Massif Central), which would have in turn increased the input of coarser grained siliciclastics in the marine realm, as exemplified by the upper Toarcian-Aalenian sequence of the same section (Elmi \& Rulleau, 1993). On the contrary, the lowermost Toarcian sequence is characterized by fine-grained siliciclastic deposits, which suggest that its deposition took place at some distance from source sediment area. In addition, a shallowing event during this interval appears incompatible with available biostratigraphic and sedimentological data, which indicate that fine-grained transgressive sediments of this age were deposited unconformably over older strata or even basement rocks in most documented areas (Hallam, 1967; Wignall, Newton \& Little, 2005; Galbrun, Gabilly \& Rasplus, 1988; Röhl \& Schmid-Röhl, 2005; Suan et al. 2011). We note, however, that several rapid and transient shallowing events interrupting a deepening trend (e.g. linked to footwall uplift of half-graben systems) might have left little evidence in available stratigraphic records but discrete hiatuses or distal storm deposits within fine-grained sequences, and might therefore have remained mostly unnoticed by previous workers. Given the relatively few detailed records available from shallow marine successions of this age, this explanation, though yet lacking supportive evidence, remains plausible and might deserve further testing.

On the other hand, it is widely recognised that the storm wave base may not have been at constant depth over geological periods (e.g. Ito et al. 2001), and should have varied as a function of palaeogeography and palaeoclimatic conditions. This is particularly true for tropical areas, where storm deposits would have been mostly formed by currents generated by tropical cyclones (Marsaglia \& Klein, 1983; PSUCLIM, 1999), the activity of which is influenced by seawater temperatures (Emanuel, 1999, 2005; Knutson et al. 2010). Nevertheless, relationships between tropical cyclones and climatic parameters are highly complex and spatially variable since the intensity, frequency, duration and track of tropical cyclones are influenced by the interplay of several other factors that include the thermal structure of the ocean or vertical wind shear (e.g. Emanuel, 2005; Knutson et al. 2010). It is noteworthy, however, that most global climate models produce a broader tropical cyclone belt and more intense tropical cyclones under higher $p \mathrm{CO}_{2}$ and warmer conditions (Fedorov, Brierley \& Emanuel, 2010; Knutson et al. 2010). In this regard, there is now robust geochemical and palaeontological evidence showing that the T-OAE was a time of severe warming, with seawater temperatures in the tropics rising more than $7^{\circ} \mathrm{C}$ across the CIE in a few hundreds of kiloyears (Bailey et al. 2003; Suan et al. 2010; Gómez, Coy \& Canales, 2008; Dera et al. 2011). Similarly, the coeval generalized transgression would have led to the formation of vast and shallow epicontinental seas, which also favour the development of intense tropical cyclones towards higher latitudes (PSUCLIM, 1999; Knutson et al. 2010). Accordingly, the appearance of storm deposits within otherwise fine-grained siliciclastic successions of SE France and Portugal during the CIE could conceivably reflect a poleward expansion of the tropical cyclone belt in response to rising seawater temperatures and accompanying transgression. Because the CIE is often considered to reflect the massive input of greenhouse gases into the oceanic-atmosphere system (Hesselbo et al. 2000, 2007; Cohen, Coe \& Kemp, 2007), this explanation would have the merit of accounting for the apparent coincidence between the interval yielding storm and gravity flow deposits, and the CIE (Fig. 5). Importantly, tropical cyclones cannot form in equatorial areas $\left(<5^{\circ}\right)$ due to insufficient Coriolis effects and are also extremely unlikely to occur at subpolar to polar latitudes, where sea surface temperatures are too low to support tropical storm development (PSUCLIM, 1999). Although high-latitude sea surface temperatures during the Early Jurassic period may have been considerably different from today, Coriolis parameters were certainly identical to present day conditions. Accordingly, an interesting prediction of the tropical storm model would be that storm and gravity-flow deposits should be overall less abundant in the high latitude and equatorial sites spanning the T-OAE. Further investigation of these yet poorly known areas will therefore constitute a crucial test of the respective validity of the two above cited hypotheses (i.e. sea-level fall versus increased cyclone activity).

An additional factor that may have exerted a strong influence on the distribution of storm and mass-flow 
deposits across the T-OAE is the efficiency of sediment transfer in relation to changes in geometries of adjacent carbonate platforms and shelves. The T-OAE indeed records a major crisis of carbonate production in shallow water carbonate platform settings (Bodin et al. 2010), reflected by a major decrease of $\mathrm{CaCO}_{3}$ accumulation in adjacent basins (Suan et al. 2008a; Léonide et al. 2012). Because carbonate platforms characterized by low carbonate production generally adopt homoclinal ramp morphologies (e.g. Schlager, 2005), this carbonate production crisis would have logically enhanced the downslope, storm-induced sediment redistribution as compared to rimmed platforms, where much of the hydraulic energy is stopped by reef-building organisms (e.g. Pomar \& Kendall, 2008). It has been proposed that the carbonate platform crisis during the T-OAE was caused by nutrient excess and changes in seawater carbonate chemistry resulting from higher $\mathrm{CO}_{2}$ levels (Suan et al. 2008a; Bodin et al. 2010). Incidentally, changes in platform geometry and sediment transfer would also account for the temporal coincidence between the CIE and the appearance of storm deposits. Because storm intensity also influences platform and shelf morphology (Quiquerez et al. 2004), these two factors are likely to have influenced each other and constitute plausible, non-mutually exclusive causes of the widespread development of storm deposits during the T-OAE.

\section{5.d. Extreme weathering of organic-rich shales and implications for palaeo-oxygenation and carbon cycling reconstructions}

The new observations presented herein also have major implications for palaeo-oxygenation and carbon cycling reconstructions, not only for the T-OAE interval but plausibly also for most ancient events of widespread oxygen deficiency. Our results indeed show that intense weathering at the study site has produced some dramatic effects on the physical and geochemical characteristics of the T-OAE succession. This weathering has led to a total destruction of the lamination and an almost complete loss of the organic carbon of the originally organic-rich Toarcian sequence over most of the exposure (Figs 3a, c, 5; see also Fig. S1 of the online Supplementary Material at http://journals.cambridge.org/geo). A similar, intense weathering of organic-rich shales has been reported in surface and subsurface studies of marine organic-rich sequences (e.g. Littke et al. 1991; Petsch, Berner \& Eglinton, 2000; L.Y.G. Rakotondratsima, unpub. Ph.D. thesis, Institut national polytechnique de Lorraine, 1995). This intense transformation of both the composition and structure of originally organic-rich, laminated strata likely involves intense organic matter oxidation as well as pyrite and carbonate loss due to exposition to $\mathrm{O}_{2}$-rich surface water and freeze-thaw cycles (Broquet, 1980; Littke et al. 1991; Petsch, Berner \& Eglinton, 2000; L.Y.G. Rakotondratsima, unpub. Ph.D. thesis, Institut national polytechnique de Lorraine, 1995). A field survey of other 'Schistes Carton' sequences in the Paris Basin (Broquet, 1980) suggests that dramatic loss of $\mathrm{CaCO}_{3}$ and organic matter can occur within a few months. To our knowledge, however, the structureless and organic-lean yellow plastic clays from the Lafarge quarry represent the most extreme documented byproduct of such weathering processes. We suggest that the intense fracturing of the sequence may have significantly enhanced, through higher permeability and water penetration, the alteration of the organic-rich shales. Differential water infiltration through faults and fractures may also help to explain the dramatic lateral changes in preservation state of the dark grey marl beds seen over a few centimetres across fractures (Fig. 3c; see also Fig. S1 in the Supplementary Material). Because intense fracturing and winter freeze-thaw cycles characterize vast modern mid- to high-latitude areas, it is likely that such extreme weathering of organic-rich deposits constitutes a widespread, possibly overlooked phenomenon. Our new data and observations thus suggest that the absence of both lamination and elevated TOC contents in clay lithologies should be interpreted with extreme caution in terms of palaeo-oxygenation when used on sedimentary sequences with very limited surface exposure.

In addition, comparison of organic carbon isotope data from weathered and non-weathered intervals indicates that intense weathering has preferentially removed the ${ }^{12} \mathrm{C}$-enriched organic fraction, leading to considerably heavier $\delta^{13} \mathrm{C}_{\text {org }}$ values in weathered samples (Fig. 5). Interestingly, the recorded differences $(2.8$ and $4 \%$ ) are comparable to those reported between the $\delta^{13} \mathrm{C}_{\text {org }}$ of black shales dominated by marine organic matter and macrofossil wood remains in Yorkshire and Argentinian sections spanning the TOAE (Hesselbo et al. 2007; Al-Suwaidi et al. 2010). Because marine organic matter is far more labile than terrestrial organic matter, we suggest that the residual organic matter in weathered samples at the study site is mainly composed of ${ }^{13} \mathrm{C}$-enriched, alteration-resistant terrestrial particles. Such a preferential preservation would explain why extremely low $\delta^{13} \mathrm{C}_{\text {org }}$ values $(<32 \%$ ) typical of the CIE in many organic rich TOAE sections (e.g. Röhl et al. 2001; Kemp et al. 2005; Sabatino et al. 2009; Hermoso et al. 2012) are absent in the weathered portion of the basal serpentinum Zone in the study site (Figs 5, 6). Our new data thus support the idea that differential preservation of organic matter may have dramatic consequences on the resulting bulk $\delta^{13} \mathrm{C}_{\text {org }}$ profiles. These biases should therefore be more systematically integrated when using the magnitude and shape of bulk $\delta^{13} \mathrm{C}_{\text {org }}$ profiles to constrain the causes of past episodes of global carbon cycle perturbations (e.g. Beerling \& Brentnall, 2007).

\section{Conclusions}

Our new sedimentological, biostratigraphical and geochemical data from southern Beaujolais, southeastern France, show that the T-OAE interval is characterized 
by laminated and organic-rich shales (up to $10 \mathrm{wt} \%$ TOC) associated with a fauna typical of oxygendepleted environments. These new results document for the first time the presence of the 'Schistes Carton' facies typical of the nearby basins in the southern Beaujolais area and show that strong oxygen deficiency expanded upon marginal marine settings close to the Central Massif high during the T-OAE. The base of the lower Toarcian sequence in the study site, however, is unusual in that it is marked by the occurrence of volumetrically important storm deposits containing tremendous concentrations of the very small, lowoxygen-tolerant gastropod Coelodiscus. The interval recording these storm deposits coincides with a marked $5 \%$ negative carbon isotope excursion and hence correlates precisely with that documenting gravity flow and storm deposits in lower latitude sections, pointing to the existence of a major tempestitic/turbiditic event over tropical areas across the T-OAE. Although several explanations remain possible at present (e.g. rapid shallowing events) we favour climatically induced changes in platform morphology and storm activity as the main drivers of these sedimentological features. In addition, our new observations are significant in showing that recent weathering has almost totally erased the main lithological and geochemical criteria (lamination and high TOC values) commonly used to identify strong oxygen depletion over most of the studied exposure and substantially modified the isotopic composition of the remaining organic carbon. Consequently, it is here suggested that: 1) extreme caution should be applied when interpreting the lack of typical black shale facies in surface exposures with very limited area coverage; and 2) differential organic matter preservation should be more systematically taken into account when discussing the causes of large carbon isotope excursions.

Acknowledgments. We acknowledge the generous logistical support of Lafarge and financial support from the Musée des Confluences de Lyon. We thank J. Fiebig and S. Hofmann (Goethe Frankfurt University) for their invaluable help with organic carbon isotope measurements and L. Nicod (Universite de Lausanne) for the thin sections. We also warmly thank all the volunteers who provided crucial help and entertainment during the fieldwork campaigns (V. Perrier, J. Schlögl, J. Milad, J. Plancq, E. Sarroca, K. Janneau, O. Ambrosini, K. Poure, V. Fischer and the members of the GeoPaleo section). G. Suan gratefully acknowledges postdoctoral support from the Alexander von Humboldt Foundation. Hugh Jenkyns and David Kemp are thanked for their detailed and constructive reviews that improved the quality of the manuscript. This is Paleorhodania contribution \#3.

\section{References}

Aigner, T. 1985. Storm depositional systems: dynamic stratigraphy in modern and ancient shallow-marine sequences. In Lecture Notes in Earth Sciences (eds G. M. Friedman, H. J. Neugebauer \& A. Seilacher), pp. 1-74. Springer-Verlag, New York.
Al-Suwaidi, A. H., Angelozzi, G. N., Baudin, F., Damborenea, S. E., Hesselbo, S. P., JenKyns, H. C., MANCENIDO, M. O. \& RiCCARDI, A. C. 2010. First record of the Early Toarcian Oceanic Anoxic Event from the Southern Hemisphere, Neuquen Basin, Argentina. Journal of the Geological Society, London 167, 633-6.

Bailey, T. R., Rosenthal, Y., McArthur, J. M., VAN DE SCHOOTBRUGge, B. \& ThiRlWALl, M. F. 2003. Paleoceanographic changes of the Late Pliensbachian Early Toarcian interval: a possible link to the genesis of an Oceanic Anoxic Event. Earth and Planetary Science Letters 212, 307-20.

BANDEL, K. \& HEMLEBEN, C. 1987. Jurassic heteropods and their modern counterparts (planktonic Gastropoda, Mollusca). Neues Jahrbuch für Geologie und Paläontologie Abhandlungen 174, 1-22.

Baudin, F., Herbin, J.-P. \& VAndenbroucke, M. 1990. Mapping and geochemical characterization of Toarcian organic matter in the Mediterranean Tethys. Organic Geochemistry 16, 677-87.

BeERling, D. J. \& BREnTNALL, S. J. 2007. Numerical evaluation of mechanisms driving Early Jurassic changes in global carbon cycling. Geology 35, 247-50.

Bodin, S., Mattioli, E., Fröhlich, S., Marshall, J. D., BoutBiB, L., LAHSini, S. \& Redfern, J. 2010. Toarcian carbon isotope shifts and nutrient changes from the Northern margin of Gondwana (High Atlas, Morocco, Jurassic): palaeoenvironmental implications. Palaeogeography, Palaeoclimatology, Palaeoecology 297, 377-90.

Bown, P. R. 1987. Taxonomy, evolution, and biostratigraphy of the Late Triassic - Early Jurassic calcareous nannofossils. Special Papers in Palaeontology 38, 1118.

Bown, P. R. \& Young, J. R. 1998. Techniques. In Calcareous Nannoplankton Biostratigraphy (ed. P. R. Bown), pp. 16-28. British Micropaleontological Press.

BROQUET, P. 1980. Les schistes bitumineux. Quelques gisements types. Leur exploitabilité. In Énergies Fossiles: Les Hydrocarbures, pp. 19-46. 266 Congrés géologique international, Section XIV, Paris, 1980, Éditions Technip.

Bucefalo Palliani, R. \& Mattioli, E. 1998. High resolution integrated microbiostratigraphy of the Lower Jurassic (late Pliensbachian early Toarcian) of central Italy. Journal of Micropalaeontology 17, 153-72.

Bucefalo Palliani, R., Mattioli, E. \& Riding, J. B. 2002. The response of marine phytoplankton and sedimentary organic matter to the early Toarcian (Lower Jurassic) oceanic anoxic event in northern England. Marine Micropaleontology 46, 223-45.

Caswell, B. A., CoE, A. L. \& Cohen, A. S. 2009. New range data for marine invertebrate species across the early Toarcian (Early Jurassic) mass extinction. Journal of the Geological Society, London 166, 859-72.

Cohen, A. S., Coe, A. L. \& Kemp, D. B. 2007. The late Palaeocene - Early Eocene and Toarcian (Early Jurassic) carbon isotope excursions: a comparison of their time scales, associated environmental changes, causes and consequences. Journal of the Geological Society, London 164, 1093-108.

Dera, G., Brigaud, B., Monna, F., Laffont, R., Puceat, E., Deconinck, J. F., Pellenard, P., JoAchimski, M. M. \& Durlet, C. 2011. Climatic ups and downs in a disturbed Jurassic world. Geology 39, 215-18.

Dera, G., Pellenard, P., Neige, P., Deconinck, J. F., Puceat, E. \& Dommergues, J. L. 2009. Distribution of clay minerals in Early Jurassic Peritethyan seas: 
palaeoclimatic significance inferred from multiproxy comparisons. Palaeogeography, Palaeoclimatology, Palaeoecology 271, 39-51.

DuARTE, L. V. \& SOARES, A. F. 1993. Eventos de natureza tempestítica e turbidítica no Toarciano inferior da Bacia Lusitaniana. Cadernos de Geografia 12, 85-9.

Duarte, L. V, Oliveira, L. C. V. \& Rodrigues, R. 2007. Carbon isotopes as a sequence stratigraphic tool: examples from the Lower and Middle Toarcian marly limestones of Portugal. Boletín Geológico y Minero 118 , $3-18$.

EINSEle, G. \& Mosebach, R. 1955. Zur Petrographie, Fossilerhaltung und Entstehung der Gesteine des Posidonienschiefers im Schwäbischen Jura. Neues Jahrbuch für Geologie und Paläontologie Abhandlungen 101, 319-30.

Elmi, S. \& RulleaU, L. 1991. Le Toarcien des carrières Lafarge (Bas-Beaujolais, France): un cadre biostratigraphique de référence pour la région Lyonnaise. Geobios 24, 315-31.

ElMI, S. \& RULLEAU, L. 1993. Le Jurassique du Beaujolais méridional, bordure orientale du Massif central, France. Geobios Mémoire Spécial 15, 139-55.

EMANUEL, K. A. 1999. Thermodynamic control of hurricane intensity. Nature 401, 665-9.

EMANUEL, K. A. 2005. Increasing destructiveness of tropical cyclones over the past 30 years. Nature 436, 686-8.

Emmanuel, L., Renard, M., Cubaynes, R., De Rafelis, M., Hermoso, M., Le Callonnec, L., Le Solleuz, A. \& REY, J. 2006. The "Schistes carton" of Quercy (Tarn, France): a lithological signature of a methane hydrate dissociation event in the Early Toarcian. Implications for correlations between Boreal and Tethyan realms. Bulletin de la Société Géologique de France 177, 23747.

Etches, S., Clarke, J. \& Callomon, J. 2009. Ammonite eggs and ammonitellae from the Kimmeridge Clay Formation (Upper Jurassic) of Dorset, England. Lethaia 42, 204-17.

ETTER, W. 1996. Pseudoplanktonic and benthic invertebrates in the Middle Jurassic Opalinum Clay, northern Switzerland. Palaeogeography, Palaeoclimatology, Palaeoeco$\log y$ 126, 325-41.

Fedorov, A. V., Brierley, C. M. \& EMANUEl, K. 2010. Tropical cyclones and permanent El Nino in the early Pliocene epoch. Nature 463, 1066-71.

FISCHER, W. 1961. Über die Bildungsbedingungen der Posidonienschiefer in Süddeutschland. Neues Jahrbuch für Geologie und Paläontologie Abhandlungen 111, 326-40.

Galbrun, B., Gabilly, J. \& Rasplus, L. 1988. Magnetostratigraphy of the Toarcian stratotype at Thouars and Airvault (Deux-Sèvres, France). Earth and Planetary Science Letters 87, 453-62.

Ghadeer, S. G. \& MacquaKer, J. H. S. 2012. The role of event beds in the preservation of organic carbon in fine-grained sediments: analyses of the sedimentological processes operating during deposition of the Whitby Mudstone Formation (Toarcian, Lower Jurassic) preserved in northeast England. Marine and Petroleum Geology 35, 309-20.

GóMEZ, J. J. \& GoY, A. 2011. Warming-driven mass extinction in the Early Toarcian (Early Jurassic) of northern and central Spain. Correlation with other time-equivalent European sections. Palaeogeography, Palaeoclimatology, Palaeoecology 306, 176-95.

Gómez, J. J., GoY, A. \& CANALES, M. L. 2008. Seawater temperature and carbon isotope variations in belemnites linked to mass extinction during the Toarcian (Early Jurassic) in Central and Northern Spain. Comparison with other European sections. Palaeogeography, Palaeoclimatology, Palaeoecology 258, 28-58.

Guex, J., Morard, A., Bartolini, A. \& Morettini, E. 2001. Découverte d'une importante lacune stratigraphique à la limite Domérien-Toarcien: implications paléoocéanographiques. Bulletin de la Société Vaudoise des Sciences Naturelles 345, 277-84.

Hallam, A. 1967. An environmental study of the Upper Domerian and Lower Toarcian in Great Britain. Philosophical Transactions of the Royal Society B 252, 393445.

HALlAM, A. \& BRADSHAW, M. J. 1979. Bituminous shales and oolithic ironstones as indicators of transgressions and regressions. Journal of the Geological Society, London, 136, 157-64.

HARRIES, P. J. \& LitTLE, C. T. S. 1999. The early Toarcian (Early Jurassic) and the Cenomanian-Turonian (Late Cretaceous) mass extinctions: similarities and contrasts. Palaeogeography, Palaeoclimatology, Palaeoecology 154, 39-66.

Hermoso, M., Le Callonnec, L., Minoletti, F., Renard, M. \& Hesselbo, S. P. 2009. Expression of the Early Toarcian negative carbon-isotope excursion in separated carbonate microfractions (Jurassic, Paris Basin). Earth and Planetary Science Letters 277, 194-203.

Hermoso, M., Minoletti, F., Rickaby, R. E. M., Hesselbo, S. P., BAudin, F. \& JenKyns, H. C. 2012. Dynamics of a stepped carbon-isotope excursion: ultra high-resolution study of Early Toarcian environmental change. Earth and Planetary Science Letters 319-320, $45-54$.

Hesselbo, S. P., Grocke, D. R., Jenkyns, H. C., BJerrum, C. J., FARrimond, P., Bell, H. S. M. \& GREeN, O. R. 2000. Massive dissociation of gas hydrate during a Jurassic oceanic anoxic event. Nature 406, 392-95.

Hesselbo, S. P., Jenkyns, H. C., Duarte, L. V. \& OLIVEIRA, L. C. V. 2007. Carbon-isotope record of the Early Jurassic (Toarcian) Oceanic Anoxic Event from fossil wood and marine carbonate (Lusitanian Basin, Portugal). Earth and Planetary Science Letters 253, 455-70.

HowARTH, M. K. 1992a. The Ammonite family Hildoceratidae in the Lower Jurassic of Britain, Part 1. Monograph of the Palaeontographical Society (London) 145(586), 1-106.

HowARTH, M. K. 1992b. The Ammonite family Hildoceratidae in the Lower Jurassic of Britain, Part 2. Monograph of the Palaeontographical Society (London) 146(590), 107-200.

Ito, M., Ishigaki, A., NishikaWA, T. \& SAito, T. 2001. Temporal variation in the wavelength of hummocky cross-stratification: implications for storm intensity through Mesozoic and Cenozoic. Geology 29, 87-9.

JENKYns, H. C. 1988. The Early Toarcian (Jurassic) Anoxic Event - stratigraphic, sedimentary, and geochemical evidence. American Journal of Science 288, 101-51.

JENKYNS, H. C. 2010. Geochemistry of oceanic anoxic events. Geochemistry Geophysics Geosystems 11 Q03004. doi:10.1029/2009GC002788.

Jenkyns, H. C., Sarti, M., Masetti, D. \& Howarth, M. K. 1985. Ammonites and stratigraphy of Lower Jurassic black shales and pelagic limestones from the Belluno Trough, Southern Alps, Italy. Eclogae Geologicae Helvetiae 78, 299-311.

Jenkyns, H. C., Grocke, D. R. \& Hesselbo, S. P. 2001. Nitrogen isotope evidence for water mass denitrification 
during the early Toarcian (Jurassic) oceanic anoxic event. Paleoceanography 16, 593-603.

KAFOUSia, N., Karakitsios, V., JENKYNS, H. C. \& MATTIOLI, E. 2011. A global event with a regional character: the Early Toarcian Oceanic Anoxic Event in the Pindos Ocean (northern Peloponnese, Greece). Geological Magazine 148, 619-31.

Kemp, D. B., Coe, A. L., Cohen, A. S. \& Schwark, L. 2005. Astronomical pacing of methane release in the Early Jurassic period. Nature 437, 396-99.

Kennedy, M. J. \& WAGneR, T. 2011. Clay mineral continental amplifier for marine carbon sequestration in a greenhouse ocean. Proceedings of the National Academy of Sciences of the USA. 108, 9776-81.

Knutson, T. R., McBride, J. L., Chan, J., Emanuel, K., Holland, G., Landsea, C., Held, I., Kossin, J. P., SRIVASTAVA, A. K. \& SUGI, M. 2010. Tropical cyclones and climate change. Nature Geoscience 3, 157-63.

Kullberg, J. C., Oloriz, F., Marques, B., Caetano, P. S. \& RocHA, R. B. 2001. Flat-pebble conglomerates: a local marker for Early Jurassic seismicity related to synrift tectonics in the Sesimbra area (Lusitanian Basin, Portugal). Sedimentary Geology 139, 49-70.

LÉOnide, P., Floquet, M., Durlet, C., BAudin, F., Pittet, B. \& LÉCUYER, C. 2012. Drowning of a carbonate platform as a precursor stage of the Early Toarcian global anoxic event (Southern Provence sub-Basin, South-east France). Sedimentology 59, 156-84.

Littke, R., Klussman, U., KroOss, B. \& LeythäUser, D. 1991. Quantification of loss of calcite, pyrite and organic matter during weathering of Toarcian black shales and effects on kerogen and bitumen characteristics. Geochimica et Cosmochimica Acta 55, 3369-78.

Mailliot, S., Mattioli, E., Bartolini, A., Baudin, F., Pittet, B. \& GueX, J. 2009. Late Pliensbachian Early Toarcian (Early Jurassic) environmental changes in an epicontinental basin of NW Europe (Causses area, central France): a micropaleontological and geochemical approach. Palaeogeography, Palaeoclimatology, Palaeoecology 273, 346-64.

Marsaglia, K. M. \& Klein, G. D. 1983. The paleogeography of Paleozoic and Mesozoic storm depositional systems. Journal of Geology 91, 117-42.

Martin, J. E., Fischer, V., Vincent, P. \& SuAN, G. 2012. A longirostrine Temnodontosaurus (Ichthyosauria) with comments on Early Jurassic ichthyosaur niche partitioning and disparity. Palaeontology 55, 995-1005.

Mattioli, E. \& ERBA, E. 1999. Synthesis of calcareous nannofossil events in Tethyan Lower and Middle Jurassic successions. Rivista Italiana di Paleontologia e Stratigrafia 105, 343-76.

Mattioli, E., Pittet, B., Petitpierre, L. \& Mailliot, S. 2009. Dramatic decrease of pelagic carbonate production by nannoplankton across the Early Toarcian anoxic event (T-OAE). Global and Planetary Change 65, 134-45.

Mattioli, E., Pittet, B., Suan, G. \& Mailliot, S. 2008. Calcareous nannoplankton changes across the early Toarcian oceanic anoxic event in the western Tethys. Paleoceanography, 23, PA3208, doi:10.1029/2007PA001435.

McArthur, J. M., Algeo, T. J., VAn de Schootbrugge, B., LI, Q. \& HOWARTH, R. J. 2008. Basinal restriction, black shales, Re-Os dating, and the Early Toarcian (Jurassic) oceanic anoxic event. Paleoceanography 23, PA4217.

Meyer, K. M. \& KuMP, L. R. 2008. Oceanic euxinia in Earth history: causes and consequences. Annual
Review of Earth and Planetary Sciences 36, 251-88. doi:10.1146/annurev. earth.36.031207.124256.

MONACO, P. 1994. Hummocky cross-stratifications and trace fossils in the Middle Toarcian of some sequences of Umbria-Marche Apennines. Geobios 27, Suppl. 3, 67988.

Myrow, P. M. \& Southard, J. B. 1996. Tempestite deposition. Journal of Sedimentary Research 66, 87587.

PÁlfy, J. \& SMith, P. L. 2000. Synchrony between Early Jurassic extinction, oceanic event, and the Karoo-Ferrar flood basalt volcanism. Geology 28, 747-50.

Petsch, S. T., Berner, R. A. \& Eglinton, T. I. 2000. A field study of the chemical weathering of ancient sedimentary organic matter. Organic Geochemistry 31, 47587.

POMAR, L. \& KENDALL, C. 2008. Architecture of carbonate platforms: a response to hydrodynamics and evolving ecology. In Controls on Carbonate Platform and Reef Development (eds J. Lukasik \& J. A. (Toni) Simo), pp. 187-216. SEPM Special Publication no. 89.

Posamentier, H. W., JerVey, M. T. \& VAil, P. R. 1988. Eustatic controls on clastic deposition I - conceptual framework. In Sea-level Changes: An Integrated Approach (eds C. K. Wilgus, H. W. Posamentier, C. A. Ross \& C. S. C. Kendall), pp. 107-154. SEPM Special Publication no. 42.

PSUCLIM, 1999. Storm activity in ancient climates. 2. An analysis using climate simulations and sedimentary structures. Journal of Geophysical Research 104(D22), 27 295-320.

Quiquerez, A., Allemand, P., Dromart, G. \& Garcia, J. P. 2004. Impact of storms on mixed carbonate and siliciclastic shelves: insights from combined diffusive and fluid-flow transport stratigraphic forward model. Basin Research 16, 431-49.

Riegraf, W., Werner, G. \& Lörcher, F. 1984. Der Posidonienschiefer: Biostratigraphie Fauna und Fazies des südwestdeutschen Untertoarciums (Lias Epsilon). Stuttgart: Enke.

RÖHL, H. J. \& SCHMID-RÖHL, A. 2005. Lower Toarcian (Upper Liassic) black shales of the Central European Epicontinental basin: a sequence stratigraphic case study from the SW German Posidonia Shale. In Deposition of Organic-Carbon-Rich Sediments: Models, Mechanisms, and Consequences (ed. N. B. Harris), pp. 165-89. SEPM Special Publications no. 82.

RÖHL, H.-J., SCHMID-RÖHL, A., OSChMANN, W., FRIMMEL, A. \& Schwark, L. 2001. The Posidonia Shale (Lower Toarcian) of SW-Germany: an oxygen-depleted ecosystem controlled by sea level and palaeoclimate. $\mathrm{Pa}$ laeogeography, Palaeoclimatology, Palaeoecology 169, 273-99.

RulleaU, L. 1997. Nouvelles observations sur le Toarcien inférieur de la région Lyonnaise: comparaisons avec les régions voisines. Géologie de la France 2, 13-22.

RULLEAU, L. 2006. Biostratigraphie et paléontologie du Lias supérieur et du Dogger de la région Lyonnaise (Eds L. Rulleau \& la Section Géologie et Paléontologie du Comité d'Entreprise Lafarge Ciments). Dedale Editions, $381 \mathrm{pp}$.

Sabatino, N., Neri, R., Bellanca, A., Jenkyns, H. C., Baudin, F., Parisi, G. \& Masetti, D. 2009. Carbon-isotope records of the Early Jurassic (Toarcian) oceanic anoxic event from the Valdorbia (UmbriaMarche Apennines) and Monte Mangart (Julian Alps) sections: palaeoceanographic and stratigraphic implications. Sedimentology 56, 1307-28. 
Schlager, W. 2005. Carbonate Sedimentology and Sequence Stratigraphy. SEPM, Concepts in Sedimentology and Paleontology vol. 8, 200 pp.

Suan, G., Mattioli, E., Pittet, B., Lécuyer, C., Suchéras-MarX, B., Duarte, L. V., Philippe, M., RegGiani, L. \& MARTINEAU, F. 2010. Secular environmental precursors to Early Toarcian (Jurassic) extreme climate changes. Earth and Planetary Science Letters 290, 448-58.

Suan, G., Mattioli, E., Pittet, B., Mailliot, S. \& LÉCUYER, C. 2008a. Evidence for major environmental perturbation prior to and during the Toarcian (Early Jurassic) oceanic anoxic event from the Lusitanian Basin, Portugal. Paleoceanography 23. doi 10.1029/2007PA001459.

Suan, G., Pittet, B., Bour, I., Mattioli, E., Duarte, L. V. \& MAILliot, S. 2008b. Duration of the Early Toarcian carbon isotope excursion deduced from spectral analysis: consequence for its possible causes. Earth and Planetary Science Letters 267, 666-79.

Suan, G., Nikitenko, B. L., Rogov, M. A., Baudin, F., SPANGENBERG, J. E., KNYAZEV, V. G., GLINSKIKH, L. A., Goryacheva, A. A., AdATte, T., Riding, J. B., FÖllmi, K. B., Pittet, B., Mattioli, E. \& LÉCUyer, C. 2011. Polar record of Early Jurassic massive carbon injection. Earth and Planetary Science Letters 312, 102-13.

Svensen, H., Planke, S., Chevallier, L., Malthe-Sorenssen, A., CORfu, F. \& JAMTVEIT,
B. 2007. Hydrothermal venting of greenhouse gases triggering Early Jurassic global warming. Earth and Planetary Science Letters 256, 554-66.

Trabucho AleXandre, J., Tuenter, E., Henstra, G. A., VAN DER ZWAN, K. J., VAN DE WAL, R. S. W., Dijkstra, H. A. \& De Boer, P. L. 2010. The mid-Cretaceous North Atlantic nutrient trap: black shales and OAEs. Paleoceanography, 25, PA4201. doi: 10.1029/2010PA001925.

VAN DE SChoOtbrugGe, B., McArthur, J. M., BAiley, T. R., Rosenthal, Y., Wright, J. D. \& Miller, K. G. 2005. Toarcian oceanic anoxic event: an assessment of global causes using belemnite $\mathrm{C}$ isotope records. Paleoceanography 20, PA3008, doi: 10.1029/2004PA001102.

WAlKeR, R. G. \& Plint, A. G. 1992. Wave- and stormdominated shallow marine systems. In Facies Models: Response to Sea Level Change (eds R. G. Walker \& N. P. James), pp. 219-38. Geological Association of Canada.

WeItschat, W. 1973. Stratigraphie und Ammoniten des Höheren Untertoarcium (oberer Lias epsilon) von NWDeutschland. Geoligisches Jahrbuch, Reihe A, Hannover, $\mathbf{8}, 3-81$.

Wignall, P. B., Newton, R. J. \& Little, C. T. S. 2005. The timing of paleoenvironmental change and causeand -effect relationships during the Early Jurassic mass extinction in Europe. American Journal of Science, 305, 1014-32. 